DOI https://doi.org/10.18551/rjoas.2018-06.58

\title{
COMMUNITY BASED MANGROVE ECOSYSTEM MANAGEMENT AT CLUNGUP BEACH OF TAMBAKREJO VILLAGE, MALANG REGENCY
}

\author{
Yustinaningrum Diah* \\ ${ }^{1}$ Environmental and Development Resources Management, Postgraduate Program, \\ Universitas Brawijaya, Indonesia \\ Hakim Abdul \\ Department of Public Administration, Faculty of Administrative Sciences, Universitas \\ Brawijaya, Indonesia
}

\author{
Purwanti Pudji \\ Department of Social Economics, Faculty of Fisheries and Marine Sciences, Universitas \\ Brawijaya, Indonesia
}

*E-mail: diahyustina@gmail.com

\begin{abstract}
The success of mangrove ecosystem management has been done through communitybased management, for example in Clungup Beach, Tambakrejo Village of Malang Regency. The management of this area successfully restored $73 \mathrm{Ha}$ of mangrove forest and able to integrate tourism activities, conservation, and empowerment of local communities. This study aims to determine the level of community participation and formulate management strategies. The study was conducted in March-July 2017 using descriptive method. The level of community participation is obtained based on its involvement in the management of the area. SWOT analysis is used in formulating management strategies. The level of community participation consists of four stages: planning, implementation, utilization and evaluation. The level of community participation at each stage is in the high category. According to Arnstein (1969), included in citizen power, where people are able to plan, implement programs that are made independently. The strategy applied is aggressive growth; utilize the power to achieve the opportunity. Priority undertaken: strengthening mangrove ecotourism management through: improving the function of education, improving the quality and comfort of tourists, improving the quality of media outreach with the improvement of sites on the internet; improving community empowerment.
\end{abstract}

\section{KEY WORDS}

Mangrove ecosystem, community participation, community-based management, strategy.

Indonesia is a country with the largest mangrove ecosystem in the world, which is about 3.49 million hectares of mangroves or nearly $21 \%$ of the world total mangrove area with good condition of 1.67 million hectares and damaged condition of 1.82 million hectares (Anonymus, 2017) This ecosystem has an important role in the management of coastal areas and oceans. Mangroves provide a wide range of ecosystem services, including nutrient cycling, soil formation, production of wood, spawning grounds, carbon storage and ecotourism (Mudiyarso et al., 2015).

Excessive mangrove utilization with no attention to the importance of the ecological side became a major threat to the sustainability of this ecosystem. The area of mangrove forest in Indonesia has decreased by $30-50 \%$, due to coastal area development, expansion of fishpond area, abrasion, and illegal logging (CIFOR, 2012).

In the last fifty years, in many developing countries, the concept of community-based mangrove management is considered essential in the sustainable use of resources. This concept emphasizes the involvement of local communities in the strategic activities of resource identification, priority development, choice and adaptation of appropriate 
technologies to formulate and implement sustainable management practices (Damastuti and Rudolf, 2017). In community-based mangrove management processes, local people have been encouraged to participate in every step of resources management and planning (Surin, 2014).

Participation means taking part in a stage or more of a process (Khairuddin, 2000). The level of community participation consists of eight ladders / levels (levels), ranging from no participation to delegation of authority to supervise (Arnstein, 1969).

In Indonesia, community-based management practices have been able to recover more than $100 \mathrm{~km} 2$ of mangrove forest (Field, 1999). One of them is the mangrove ecosystems in Clungup Beach, Tambakrejo Village, Malang Regency, East Java, where around year 1999 mangrove forest in this area suffered severe damage due to illegal logging and conversion of land into ponds and plantations. The successful management of this area is able to rehabilitate $73 \mathrm{Ha}$ of mangrove forest from the total area of $81 \mathrm{Ha}$. In 2014, this area began to be used as an ecotourism area while maintaining the sustainability of its ecosystem. Efforts to manage the area get appreciation from the Government as a conservation area with the best management version of Adhibakti Mina Bahari 2015 in the category of Coastal Area Development Tangguh (PKPT) and Kalpataru East Java Province Environmental Pioneer category in 2016 (Harahab, 2017).

Given the vulnerability of mangrove ecosystems and the importance of the role of communities in maintaining these ecosystems, the question arises about the active role of local communities in Clungup Beach, so that mangrove ecosystems in this area are maintained and sustainable. This study aims to analyze the level of community participation in ecosystem management and formulate strategies management of community-based mangrove ecosystems as one of the efforts to conserve sustainable coastal resources. The result of this research is expected to be one of the considerations of mangrove ecosystem management in Clungup Beach, Tambakrejo Village, Sumbermanjing Wetan Subdistrict, Malang Regency.

\section{METHODS OF RESEARCH}

The research was done by descriptive method. The technique used is a survey by using questionnaires and interviews as the main data collection tool. Data collection techniques were conducted by interviewing and filling out the questionnaires directly from the surrounding community and informants (area managers, Tambakrejo Village Head, DKP Malang Regency, Malang Environment Agency, Culture and Tourism Office of Malang Regency, KKP). Data collection is also obtained through observation and literature study methods.

Determination of respondents was taken using "purposive sampling" technique, where the researcher had certain considerations in sampling or sampling for a particular purpose (Natsir, 2005). In this case the respondent is a community around the area, especially Sendang Biru VIllage either directly or indirectly involved in the management of mangrove ecosystem (group members and non-members of the group, head of household, indigenous or immigrants with a minimum five-year stay). Number of respondents taken as many as 40 Head of Family.

This research takes place in Mangrove Ecotourism Area in Clungup Beach, Sendang Biru Village, Tambakrejo Village, Malang Regency, East Java. The study was conducted for 5 months starting from March until July 2017. The community participation level was obtained based on community involvement in mangrove ecosystem management stage, which cover: planning, implementation, evaluation and utilization (Soetomo, 2008).

Furthermore, to identify the level of community participation in the management of mangrove ecosystems the concept of participation, this divides into eight levels of participation as shown in figure 1 below (Arstein, 1969).

Eight ladder levels of community participation:

- Manipulation, public participation is only used as a tool of publication, there is no participation at all. 
- Therapy, community engagement is meant to change the pattern or way of thinking of the community involved rather than to get advice or input from them.

- Informing, the public is informed of the rights, responsibilities, and alternative options to participate. But the emphasis is more on providing information that is one-way participation.

- Consultation, the community began to get involved providing ideas and inputs that are important factors to lead to a full form of participation. However, this way has a low success rate, because there is no guarantee that the idea from society will be noticed and used.

- Placation, society begins to have influence although in some cases still determined by those who have power.

- Partnership, at this level, power is shared among parties representing the community with stakeholders based on mutual agreement.

- Delegated Power, communities are provided with the authority to make strategic decisions and have the authority to plan and determine that the programs implemented are beneficial to them.

- Citizen Center, the community has full power to manage the program in the form of authority to plan, execute and conduct supervision of the program it makes independently.

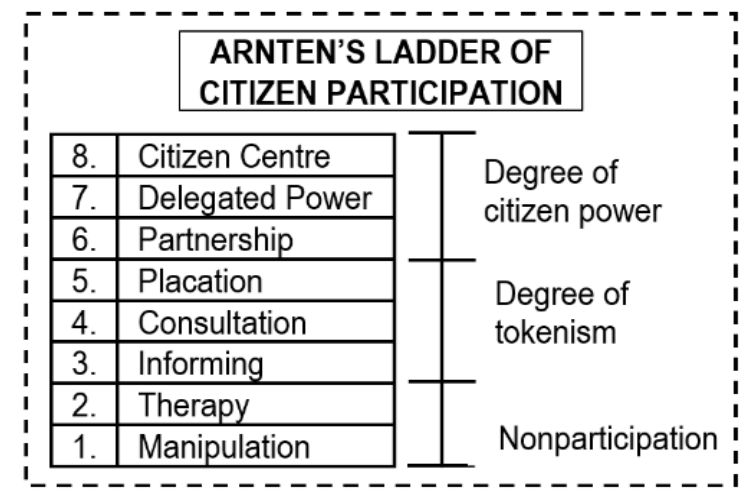

Figure 1 - Eight levels of community participation (Arnstein, 1969)

In this research, SWOT analysis approach is used to formulate community-based mangrove ecosystem management strategy. The SWOT analysis aims to identify various factors systematically in formulating a strategy based on logic by maximizing existing strengths and opportunities simultaneously and minimizing existing weaknesses and threats simultaneously (Rangkuti, 2006). Acording to Purwanti et al., (2017) the stages of SWOT analysis performed include: (a) Identification of internal and external factors; (b) Weights, relative weights, and scores; (c) SWOT matrix analysis; (d) Grand Strategy Analysis.

\section{RESULTS AND DISCUSSION}

Respondent's Characteristic. The majority of respondents are at the productive age, where the oldest reponden age 77 years and the youngest age 21 years. In general, age distribution by class is obtained: Age 21 - 31 years old 20\%, Age $32-42$ years old 27,5\%, Age $43-53$ year $30 \%$, Age $54-64$ year $17,5 \%$ and Age $>64$ years at $5 \%$. Thus, communities around the area have great potential to be involved in the management of mangrove ecosystems.

Most of the respondents had very low level of education, only graduated from primary school equal to $57,5 \%$, then lower education level (junior high) equal to $27,5 \%$ and respondents who have medium education level (pass senior high school) equal to $15 \%$. As is known, most of the respondents are farm laborers and fishermen so choose to work instead 
of continuing school. However, the community has a high knowledge of the functions and benefits of mangroves.

The lowest income of respondents is Rp500.000,00 per month and highest Rp5.000.000,00 per month. The majority of people in this region have an average income with sufficient category, which ranges from Rp 2,000,000,00 to Rp 2,900,000,00 per month. This is because most people have alternative livelihoods, one of them as a tour guide as a positive impact of the use of the area through ecotourism approach.

Community Participation Level. The role of communities around the mangrove ecosystem area in Clungup Beach is an important key to the success of the management of the area where the implementation requires long-term consistency and active participation from the community. Distribution level of community participation at each stage can be seen in picture 2 below:

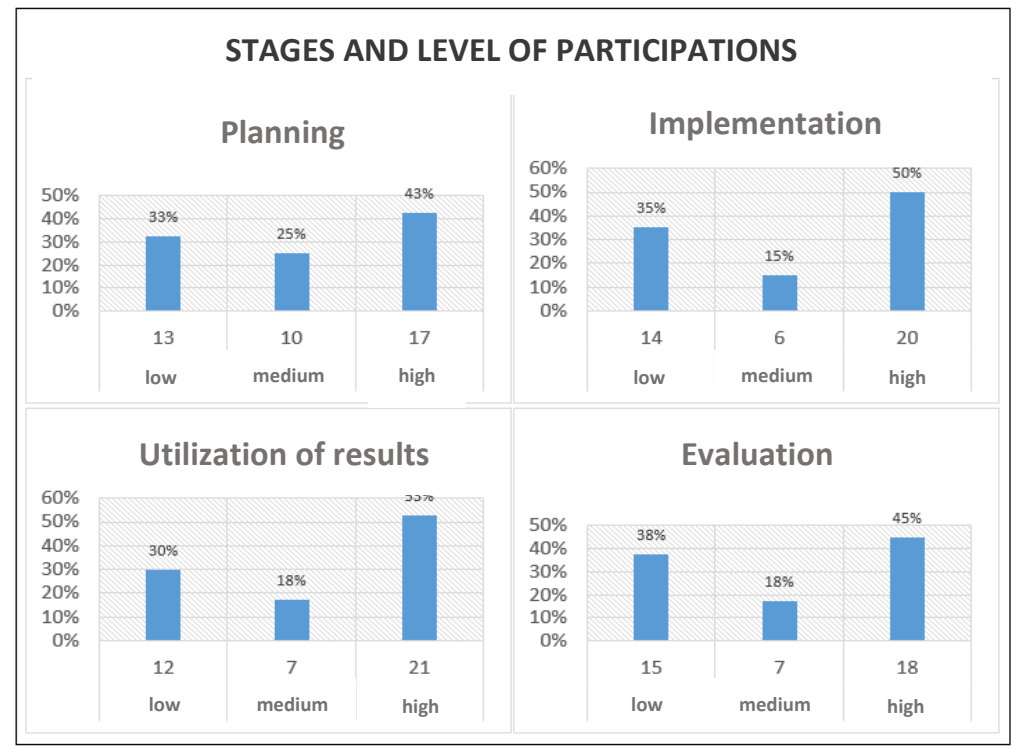

Figure 2 - Distribution of Community Participation Level in Mangrove Ecosystem Management

Planning Stage. The level of participation is measured through the extent of community involvement in planning activities which include the level of attendance and awareness in counseling activities, socialization, meetings / meetings held by the government or by groups / institutions and activeness in expressing opinions.

Implementation Phase. The level of participation is measured by the presence and awareness and involvement of family members in the rehabilitation of mangrove ecosystems through the planting of mangrove vegetation.

Evaluation Stage. The level of participation is measured by looking at the extent of community involvement and role in the evaluation and maintenance of mangrove vegetation that has been planted and already in the CMC area

Phase Utilization. Measured from the benefits gained from the management of mangrove ecosystems

Based on Figure 2, the general level of community participation is high. This participation rate according to Arnstein (1969) is included in citizen power, in which the society is able to plan, implement the program it creates independently. The community is active in following extension activities and meetings. The community can carry out the planting of mangrove vegetation independently. Mangrove seeds obtained through the contribution of visitors in addition through assistance programs from the government and cooperation with educational institutions.

The community also has a high awareness of the sustainability of mangrove vegetation, willing to re-stitch mangrove that died or carried away and eradicate pests attached to mangrove seedlings. In addition, the active role of the community is high by 
applying a ban to destroy and revoke mangrove vegetation in the mangrove ecosystem area in Clungup Beach. As is known, mangrove ecosystem area in Clungup Beach is a conservation area so it is not allowed to utilize mangrove vegetation or conduct fishing / marine life within the area.

At the planning, implementation and evaluation / maintenance stages, community involvement is quite high. This is because some respondents who are members of the Bhakti Alam Foundation are actively involved in the management of the mangrove ecosystem. However, there are respondents who opposed the management of this area, especially fishermen, because their activities are limited by the conservation area of the mangrove ecosystem, so the level of participation in the low level.

The use of ecosystem as an ecotourism area can integrate tourism activities, conservation and empowerment of local communities. Increased revenues from the utilization of mangrove ecosystems for ecotourism areas, making a lot of tourists who visit, so the number of homestay homes or lodging, places to eat / stalls around the area. In addition, there are alternative livelihoods as tour guides, motorcycle taxi drivers, and parking attendants. Most of the communities, both group members and non-members, have a positive impact with ecotourism in the CMC area.

Mangrove Ecosystem Management Strategy:

Strength:

- Potential area of mangrove ecosystem (Clungup Mangrove Conservation). This area has a total area of \pm 210 ha with complete features such as mangrove forests, coral reefs, sandy beaches, and hills.

- Utilization as ecotourism area. Utilization of mangrove ecosystem as an ecotourism area by applying strict rules for visitors to make sustainability and cleanliness of the area is maintained so that the main attraction for visitors.

- The level of community participation in the management of mangrove ecosystems. This can be seen from the analysis of the level of community participation that has been done, where the community directly involved and play an active role in the management of mangrove ecosystems starting from the stages of planning, implementation, utilization and evaluation.

- The existence of Yayasan Bhakti Alam Sendang Biru in the management of mangrove ecosystem. CMC area manager, the Bhakti Alam Sendang Biru Foundation plays an important role in the successful management of mangrove ecosystems in the region. This institution is a container as well as a driver to encourage community participation in the management of mangrove ecosystems. The Institution of Bhakti Alam Sendang Biru Foundation has a legal basic through the Decree of the Minister of Justice and Human Rights of the Republic of Indonesia Number AHU-0015997.AH.01.04 of 2016 on Ratification of the Establishment of Legal Entity of Bhakti Alam Sendang Biru Foundation, set in Jakarta on 21 March 2016.

- The benefits of mangrove ecosystem management for the community. The existence of mangrove ecosystem management provides positive benefits for the community, which is an increase in incomes of communities around the area.

Weakness:

- The condition of the road to the main area. The condition of the road to the main location of the CMC area after parking the vehicle, quite bad. Existing roads are perforated at various points and hardening has not yet been done. If the rainy season the road is muddy and slippery so must be careful to pass through.

- Some communities oppose the management of mangrove ecosystems. Some communities, especially fishermen, are opposed to the management of mangrove ecosystems. This is because they cannot do any fishing or other biota in this area, so the management of this area is considered not to provide benefits.

- Waste management. To overcome the garbage coming from the visitors, the manager implements the rule that every visitor's luggage is checked and recorded. If there is trash left behind, a fine of Rp100,000.00 per item is required. This is effective to reduce the 
amount of garbage coming from visitors. It is different with garbage that is came from outside, carried by currents from other places as well as waste discharges from fishing vessels or boats that anchored in the harbor near the CMC area. Waste management that has been collected is currently only temporary, in this case only limited to be collected (centralized) to be discharged to landfill/collector, there is no sustainable waste management effort.

- The ability to produce refined products based mangrove. Currently, the manager of the area is the foundation of natural blue bhakti yayasan still not developed mangrove-based processed.

Opportunity:

- Cooperation in mangrove rehabilitation activities. Management of mangrove ecosystem area in Clungup Beach has done a lot of mangrove rehabilitation cooperation, one of them with Universitas Brawijaya Malang.

- Government support in mangrove ecosystem management. Government support either through central or regional government in the form of assistance, provision of infrastructure has been done for the preservation of mangrove ecosystem in Clungup Beach. Among them are the provision of mangrove seeds, the construction of bridges, generator assistance, ship engines, mangrove tracking.

- Village Regulation Tambakrejo No. 03 of 2015 on Customary Law, Administration, and Development as well as the Environment. In addition to regulations on mangrove management on a national basis that can be used as the basis of management, this area also has a rule issued by the village as support for conservation of mangrove ecosystems in Clungup Beach, namely Village Regulation Tambakrejo No. 03 of 2015 About Customary Law, Administration, and Development and Environment Life. The rule mention that one of the core zones of the mangrove ecosystem is in Clungup Beach.

- Demand for tourism. Utilization of mangrove ecosystems in Clungup Beach as an ecotourism area started in 2014, has made this area one of the favorite tourist destinations. The increase in the number of tourists, considering the region has a beautiful panorama complete with beaches and hills.

- South Cross Road Malang Regency. Sendang Biru Area is crossed by a wide 7 to $8 \mathrm{~m}$ highway, with good road quality making it easier for tourists to come and visit the Mangrove Ecotourism Area on Clungup Beach.

Threats:

- The presence of migrant communities. The existence of Fishery Port of Pondok Dadap Sendang Biru in this region makes a lot of migrants among others fishermen andon, crew, fish traders and so on. Based on the results of interviews, most of the mangrove damage caused by immigrant residents.

- Resource use conflict. In its implementation, there has been a conflict between Perum Perhutani as the owner of the legality of the region and the community of the area management, which stems from the unclear in terms of land tenure and the status of area management by the community groups. The Regulation of the Minister of Environment and Forestry of the Republic of Indonesia No. P.39 / MENLHK / SETJEN / KUM.I / 6/2017 on Social Forestry in Perum Perhutani Working Area issued on 4 July 2017, became the basis of the management (community groups) Permit for Social Forestry Utilization (IPHPS) which is currently in the process of issuing permits.

- Awareness of the tourists about the environment. As one of the favorite ecotourism destinations, an increase in the number of visitors can be a positive value for the development of the region. Nevertheless, the awareness of visitors for environmental sustainability remains a threat to the region. Increased awareness of visitors to the environment is done by applying strict rules, one of which is a ban on disposing of garbage inside the area and limiting the number of visitors.

- The Destruction of mangrove ecosystem. Mangrove ecosystems in this area suffered severe damage in the year 1999 due to illegal logging, conversion of land into fishponds, farmland / plantation. Since 2005, mangrove conservation efforts have been made and 
have improved significantly. However, the destruction of ecosystems by irresponsible persons remains a major threat.

- Environmental pollution. The area of mangrove ecosystem in Clungup Beach is near Pondokdadap Fishery Port area or better known as TPI Sendangbiru. The negative impact of the presence of the ship and anchor mooring activities, the landing and marketing of fish, as well as other activities in the harbor form where solid and liquid wastes into the causes of environmental pollution. Types of waste to be disposed of activity ships docked in general form of garbage plastic bottles, plastic bags, and the rest of the fishing gear (fishing lines, nets and ropes float), discharge residual water used to wash in the pool area port, the exhaust of diesel used, leftovers, plastic bottles, waste bins and plastic waste, and spilled pieces of fish.

Table 1 Matrik IFAS

\begin{tabular}{|c|c|c|c|c|c|c|c|c|}
\hline & \multicolumn{4}{|l|}{ Matrik IFAS } & \multicolumn{4}{|l|}{ Matrik EFAS } \\
\hline Num. & Strength Variables & $\begin{array}{l}\text { Relative } \\
\text { Weights }\end{array}$ & Rating & Score & Variable Opportunities & $\begin{array}{l}\text { Relative } \\
\text { Weights }\end{array}$ & Rating & Score \\
\hline 1. & $\begin{array}{l}\text { Potential area of mangrove } \\
\text { ecosystem (Clungup } \\
\text { Mangrove Conservation) }\end{array}$ & 0,097 & 3 & 0,291 & $\begin{array}{l}\text { Cooperation in mangrove } \\
\text { rehabilitation }\end{array}$ & 0,118 & 4 & 0,472 \\
\hline 2. & $\begin{array}{l}\text { Utilization of ecosystem as } \\
\text { ecotourism area }\end{array}$ & 0,129 & 4 & 0,516 & $\begin{array}{lr}\text { Government } & \text { support in } \\
\text { mangrove } & \text { ecosystem } \\
\text { management } & \\
\end{array}$ & 0,118 & 4 & 0,472 \\
\hline 3. & $\begin{array}{l}\text { The level of community } \\
\text { participation in the } \\
\text { management of mangrove } \\
\text { ecosystems }\end{array}$ & 0,129 & 3 & 0,387 & Demand for tourism & 0,118 & 4 & 0,472 \\
\hline 4. & $\begin{array}{l}\text { The existence of Yayasan } \\
\text { Bhakti Alam Sendang Biru } \\
\text { in the management of } \\
\text { mangrove ecosystem }\end{array}$ & 0,129 & 4 & 0,516 & $\begin{array}{lr}\text { Village } & \text { Regulation } \\
\text { Tambakrejo Num.03 Year } \\
2015 \text { on Customary Law, } \\
\text { Administration, } & \text { and } \\
\text { Development } & \text { and } \\
\text { Environment } & \\
\end{array}$ & 0,088 & 3 & 0,264 \\
\hline \multirow[t]{2}{*}{5.} & $\begin{array}{l}\text { The benefits of mangrove } \\
\text { ecosystem management } \\
\text { for the community }\end{array}$ & 0,097 & 3 & 0,291 & $\begin{array}{l}\text { South Cross Road Malang } \\
\text { Regency }\end{array}$ & 0,088 & 3 & 0,264 \\
\hline & Total & 0,581 & \multicolumn{2}{|l|}{2,001} & Total & 0,53 & \multicolumn{2}{|l|}{1,944} \\
\hline Num. & Weakness Variables & $\begin{array}{l}\text { Relative } \\
\text { Weights }\end{array}$ & Rating & Score & Threat Variable & $\begin{array}{l}\text { Relative } \\
\text { Weights }\end{array}$ & Rating & Score \\
\hline 1. & $\begin{array}{l}\text { The condition of the road } \\
\text { to the main area }\end{array}$ & 0,097 & 3 & 0,290 & $\begin{array}{l}\text { The presence of migrant } \\
\text { communities }\end{array}$ & 0,088 & 2 & 0,176 \\
\hline 2. & $\begin{array}{l}\text { Some communities oppose } \\
\text { the management of } \\
\text { mangrove ecosystems }\end{array}$ & 0,129 & 2 & 0,258 & $\begin{array}{l}\text { Destruction of Mangrove } \\
\text { Ecosystem }\end{array}$ & 0,088 & 3 & 0,264 \\
\hline 3. & Waste management & 0,097 & 3 & 0,290 & Environmental pollution & 0,088 & 3 & 0,264 \\
\hline 4. & $\begin{array}{l}\text { The ability to produce } \\
\text { refined products based } \\
\text { mangrove }\end{array}$ & 0,097 & 3 & 0,290 & Resource use conflict & 0,118 & 4 & 0,472 \\
\hline \multicolumn{5}{|c|}{$\mathrm{C}_{\mathrm{C}} \mathrm{C}$} & $\begin{array}{l}\text { Awareness of the tourists } \\
\text { about the environment }\end{array}$ & 0,088 & 4 & 0,352 \\
\hline \multicolumn{2}{|l|}{ Total } & 0,419 & \multicolumn{2}{|l|}{1,128} & Total & 0,47 & \multicolumn{2}{|l|}{1,528} \\
\hline \multicolumn{2}{|c|}{ Grand Total Internal Factors } & 1 & \multicolumn{2}{|l|}{3,129} & $\begin{array}{lll}\text { Grand } & \text { Total } & \text { External } \\
\text { Factors } & & \\
\end{array}$ & 1 & \multicolumn{2}{|l|}{3,472} \\
\hline
\end{tabular}

SWOT Matrix Analysis:

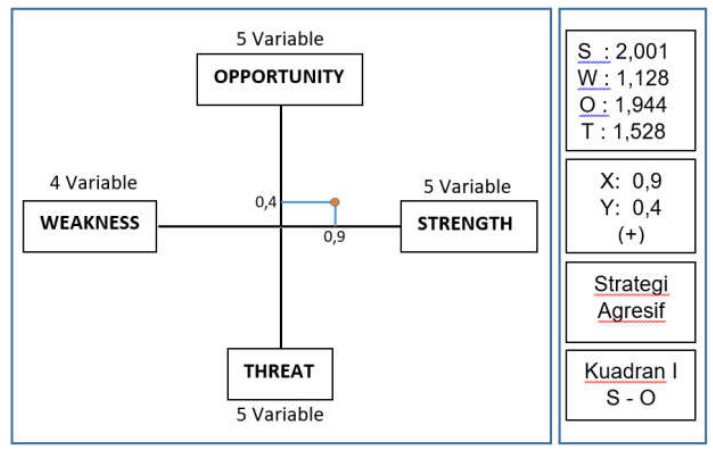

Figure 3 - Grand Strategy Matrix 
Community Based Mangrove Ecosystem Management Strategy:

Based on internal and external factors in the management of mangrove ecosystems in Clungup Beach, the strategy obtained is an aggressive strategy that is in quadrant I. This strategy is prepared by utilizing the strengths to achieve the opportunity. Community-based mangrove ecosystem management strategies in Clungup Beach are:

- Strengthening Mangrove Ecotourism Management. (a) Improving the educational function of mangroves. This area can be used as an environmental learning center, especially mangroves by providing information on the potential and superiority of mangrove vegetation that is packaged in an interesting and communicative way; (b) Improving the quality and comfort of visitors is a priority in ecotourism management. Area managers need to establish Standard Operating Procedures, improve supporting facilities and infrastructures such as: repairing access roads from parking, providing health facilities such as health posts and first aid kits, providing souvenir shops and meals; improving the quality of communication media of the area manager with web / website improvements on the internet so that it can be accessed by anyone and anytime.

- Increasing community empowerment. Community participation in the management of mangrove ecosystems in Clungup Beach is an important key to the successful management of the area. However, there are still some communities who oppose the management of this area. Therefore, it is necessary to provide assistance / mediator from Dinas Perikanan and local apparatuses, through the establishment of a dialogue forum between the managers and community leaders to support the sustainability of management.

Need support / assistance from related agencies including the Department of Fisheries, Department of Culture and Tourism of Malang Regency in improving the empowerment of surrounding communities. One of them is the establishment of food processing and handicraft processing business group from fishery and non-fishery products (mangrove based) and product marketing. As is known, this area became one of the favorite tourist destinations that the number of visitors increased each year. The visitors are the market share of the products that will be produced later. Provision of souvenir shops or souvenirs typical of this region can be one of the marketing media. Besides the provision of that concept of natural eating-place with typical menus of fishery products such as grilled fish or seafood, can be one of the tourist attraction. The involvement of all elements of society, including fishermen therein in utilization of mangrove ecosystems as ecotourism will minimize conflict, so the management of this area can be accepted by the whole society.

\section{CONCLUSION}

The level of community participation in mangrove ecosystem management in Clungup Beach is included in the high category. This participation rate according to Arnstein (1969) is included in citizen power, in which the society is able to plan, implement the program it creates independently.

The current ecosystem management is good enough with aggressive value $(0.9,0.4)$. This area is managed by Yayasan Bhakti Alam Sendang Biru initiated by the community. The Foundation was established in 2014 and officially established on March 21, 2016, based on Decree of the Minister of Justice and Human Rights of the Republic of Indonesia Number AHU-0015997.AH.01.04.

The strategy applied is aggressive growth, harnessing the strength it has to achieve the opportunity. The strengthening of mangrove ecotourism management needs to be done through improvement of education function about mangrove, improvement of quality and comfort of visitors, improvement of media quality of area manager with web / website improvement on internet.

Increased community empowerment necessary support and assistance of the Department of Fisheries and Culture and Tourism Malang through the establishment of the groups of business processing of food and craft derived from the fishery and non-fishery (based mangrove) and marketing their products. 


\section{ACKNOWLEDGEMENTS}

The authors thank to Indonesia's Ministry of Marine Affairs and Fisheries who have provided funding for this research.

\section{REFERENCES}

1. Anonymous. 2017. Peraturan Menteri Bidang Koordinator Perekonomian Republik Indonesia Selaku Ketua Pengarah Tim Koordinasi Nasional Pengelolaan Ekosistem Mangrove Nomor 4 Tahun 2017 Tentang Kebijakan, Strategi, Progra, Dan Indikator Kinerja Pengelolaan Ekosistem Mangrove Nasional. Jakarta.

2. Arnstein, S.R. 1969. A ladder of Citizen Participation. JAIP, 35 [4] : 216-224.

3. Center for International Forestry Research (CIFOR). 2012. Mangrove adalah Salah Satu Hutan Terkaya Karbon Di Kawasan Tropis. Jurnal brief. 12(1):1

4. Damastuti, E., Rudolf de Groot. 2017. Effectiveness of community-based mangrove management for sustainable resource use and livehood support: A case study of four villagesin Central Java, Indonesia. Journal of Environmental Management. 203 (2017) 510-521.

5. Field, C.D., 1999. Rehabilitation of mangrove ecosystems: an overview. Mar. Pollut. Bull. 37, 383-392.

6. Harahab, N., Setiawan, 2017. Suitability Index of Mangrove Ecotourism In Malang Regency. Brawijaya University. ECSOFiM: Journal of Economic and Social of Fisheries and Marine, pp.153-165.

7. Khairuddin, SS. 2000. Pembangunan Masyarakat. Yogyakarta: Liberty.

8. Mudiyarso D, et all. 2015. The Potential of Indonesian Mangrove Forests For Global Climate Change Mitigation. Nature Climate Change. Vol 5. December 2015.

9. Natsir, M. 2005. Metode Penelitian. Jakarta: PT Ghalia Indonesia.

10. On-prom, Surin. 2014. Community-Based Mangrove Forest Management In Thailand: Key Lesson Learned For Environmental Risk Management. Sustainable Living with Environmental Risk. DOI10.1007/978-4-431-54804-1_8.

11. Purwanti, Pudji., Susilo, Edi., Handayani, Erlinda. 2017. Pengelolaan Hutan Mangrove Berkelanjutan Pendekatan Kelembagaan dan Insentif Ekonomi. Malang: UB Press.

12. Rangkuti, Freddy. 2006. Analisis SWOT: Teknik Membedah Kasus Bisnis. Jakarta: PT. Gramedia Pustaka Utama.

13. Soetomo. 2008. Strategi-Strategi Pembangunan Masyarakat. Yogyakarta: Pustaka Pelajar. 